[Legal Act of Ukraine] (2013). https://zakon.rada.gov.ua/ rada/show/v1277731-13\#n3

[Legal Act of Ukraine] (2019). https://w1.c1.rada.gov.ua/ pls/zweb2/webproc4_1?pf3511=66516

Nechyporenko, A. V., and Mamalyha, A. V. "Borhova bezpeka Ukrainy: sutnist ta suchasnyi stan" [Debt Security of Ukraine: Essence and Current State]. Zbirnyk naukovykh prats Universytetu DFS Ukrainy, no. 2 (2019): 188-201.

Ofitsiinyi sait Ministerstva finansiv Ukrainy. http://minfin. gov.ua

Reformuvannia podatkovoi systemy Ukrainy: suchasni vyklyky ta oriientyry [Reforming the Ukrainian Tax System: Current Challenges and Benchmarks]. Kyiv: TOV «Novyi druk», 2015.
Rehuliatyvnyi potentsial finansovoho rynku $v$ umovakh hlobalnykh vyklykiv [The Regulatory Potential of the Financial Market in the Face of Global Challenges]. Irpin: NUDPSU, 2016.

Varnalii, Z. S., and Onyshchenko, S. V. "Suchasni tendentsii strukturnykh skladovykh finansovoi bezpeky Ukrainy $v$ umovakh hlobalnykh peretvoren" [Current Trends of Structural Components of Financial Security of Ukraine in the Context of Global Transformations]. Formuvannia rynkovoi ekonomiky v Ukrainy, vol. 1, no. 35 (2016): 75-80.

Yermoshenko, M. M., and Horiacheva, K. S. Finansova skladova ekonomichnoi bezpeky: derzhava i pidpryiemstvo [Financial Component of Economic Security: the State and the Enterprise]. Kyiv: Natsionalna akademiia upravlinnia, 2010.

\title{
IMPROVEMENT OF THE METHODOLOGY TO CONTROL RISK OF BANK CUSTOMERS IN THE CONTEXT OF IMPLEMENTATION OF AN EFFECTIVE RISK-BASED APPROACH
}

๑2019 PLESKUN I. V.

UDC 336.71:005.334

JEL: G21; G29

\section{Pleskun I. V. Improvement of the Methodology to Control Risk of Bank Customers in the Context of Implementation of an Effective Risk-Based Approach}

The article presents a structural-logical composition of the results of generalization of the approaches of scholars to the classification of bank risks. The feasibility of improving the risk-oriented approach is substantiated in accordance with the issues of prevention and counterance of corruption risks and modern changes in the financial monitoring system in the context of the development of mechanisms for risk control and assessment. A fragment of decomposition of the process of creating a model of risk control of customers in the context of implementing a risk-oriented approach is presented, consisting of three successive steps: analysis of the external and internal environment of risk control of the customers as subjects of primary financial monitoring; formation and testing of the risk map of customers as subjects of primary financial monitoring; implementation of controls in case of high-risk customers.

Keywords: bank, risk, control, risk-oriented approach, risk assessment.

DOl: $h$ ttps://doi.org/10.32983/2222-4459-2019-12-302-310

Fig.: 5. Bibl.: 25.

Pleskun Inna V. - Postgraduate Student of the Department of Banking and Financial Services, Simon Kuznets Kharkiv National University of Economics (9a Nauky Ave., Kharkiv, 61166, Ukraine)

E-mail: inna.pleskun@hneu.net

ORCID: https://orcid.org/0000-0002-6974-8282

УДК 336.71:005.334

JEL: G21; G29

Плескун I. В. Удосконалення методичного інструментарію ризик-контролю клієнтів банку в контексті реалізації ефрективного ризик-орієнтованого підходу

У статті представлено структурно-логічну композицію результатів узагальнення підходів науковиів до класифікації банківських ризиків. Обгрунтовано доцільність удосконалення ризик-орієнтованого підходу відповідно до питань запобігання та протидії корупційним ризикам і сучасних змін у системі фрінансового моніторингу в контексті розвитку механізмів контролю й оцінки ризиків. Наведено фрагмент декомпозиції процесу створення моделі ризик-контролю клієнтів у контексті реалізації ризик-орієнтованого підходу, що складається з трьох послідовних етапів: аналізу зовнішнього та внутрішнього середовища ризик-контролю клієнтів суб'єктів первинного фінансового моніторингу; формування та апробації карти ризиків клієнтів суб'єктів первинного фінансового моніторингу; впровадження заходів контролю щодо клієнтів з високим рівнем ризику.

Ключові слова: банк, ризик, контроль, ризик-орієнтований підхід, оцінка ризиків.

Puс.: 5. Бібл.: 25 .

Плескун Інна Володимирівна - аспірантка кафедри банківської справи і фінансових послуг, Харківський національний економічний університет ім. С. Кузнеия (просп. Науки, 9а, Харків, 61166, Україна)

E-mail: inna.pleskun@hneu.net

ORCID: https://orcid.org/0000-0002-6974-8282
УДК 336.71:005.334

JEL: G21; G29

Плескун И. В. Усовершенствование методического инструментария риск-контроля клиентов банка в контексте реализации эффрективного риск-ориентированного подхода B статье представлена структурно-логическая композиция результатов обобщения подходов ученых к классификации банковских рисков. Обоснована иелесообразность совершенствования риск-ориентированного подхода в соответствии с вопросами предотвращения и противодействия коррупционным рискам и современных изменений в системе финансового мониторинга в контексте развития механизмов контроля и оценки рисков. Приведен фрагмент декомпозиции процесса создания модели риск-контроля клиентов в контексте реализации риск-ориентированного подхода, состоящий из трех последовательных этапов: анализа внешней и внутренней среды риск-контроля клиентов субъектов первичного финансового мониторинга; формирования и апробации карты рисков клиентов субъектов первичного финансового мониторинга; внедрения мер контроля в отношении клиентов с высоким уровнем риска.

Ключевые слова: банк, риск, контроль, риск-ориентированный подход, оценка рисков.

Puc.: 5. Библ.: 25.

Плескун Инна Владимировна - аспирантка кафедры банковского дела и финансовых услуг, Харьковский национальный экономический университет им. С. Кузнеца (просп. Науки, 9а, Харьков, 61166, Украина)

E-mail: inna.pleskun@hneu.net

ORCID: https://orcid.org/0000-0002-6974-8282 
$\mathrm{T}$ The practice of banking includes a great number of mechanisms to manage the main types of risks: credit, liquidity, market and operational risk, including risks associated with money laundering. The statistics presented in reports of the State Financial Monitoring Service of Ukraine allow to prove that banks continue to underestimate their vulnerability to ML / TF risks, or try to manage them using traditional methods. The results of the analysis confirm the need to achieve the strategic goal - the effective identification, control and minimization of risks, which should be of key importance in the field of combating money laundering, including through the implementation of comprehensive preventive measures. A special role in ensuring the development of the economy and maintaining financial stability in the country is played by the banking sector. Banks are the most active entities in the reporting system, they send the largest number of reports about transactions subject to financial monitoring. This is evidenced by the general trends - during 2018, 9871608 million reports were received from banks, which is $99.02 \%$ of the total number of reports.

Under modern conditions, the sphere of financial relations, in particular, banking, requires constant monitoring, taking into account the increasing influence of both global and internal risks.

The fundamental changes in the financial monitoring system include the development of the existing mechanisms, use of methodological tools in the aspect of improving the risk-based approach (RBS). It is RBA that is applied to REs and aimed to analyze the processes of risk identification and classification, which has determined the aim of the article.

The scientific publications of foreign and Ukrainian scientists, including P. S. Rose, J. W. Kolari [1], M. C. Turk [2], N. M. Vnukova [3; 4; 7], Zh. O. Andriichenko [5; 6], S. A. Achkasova [7; 8], O. I. Baranovskyi [9], S. B. Yegorychev [10], V. V. Kovalenko [11] deal with studying problematic aspects associated with the risk of money laundering.

A significant contribution to the development of the risk assessment and risk management system for antimoney laundering and countering the financing of terrorist (AML / CFT) is made by O. O. Hlushchenko, I. B. Semehen [12]. Work [7] presents the theoretical principles and methodological and practical recommendations for assessing the impact of the level of state regulation and supervision on the development of a risk-based AML / CFT system in Ukraine. In [13], the authors systematize practical recommendations on searching models for assessment, control and effective risk management to ensure counteraction to money laundering. V. V. Kovalenko focuses on the definition of modern approaches to risk management in banking, analyzes new types of banking

Fundamental state budget theme No. 54 / 2018-2020 "Risk-oriented approach in ensuring counteraction to money laundering, terrorism financing and the proliferation of weapons of mass destruction". risks, the existence of which is associated with destabilizing processes in the financial market and defines the main directions for improving the risk management system in banks [14].

It is worth noting that under modern conditions of changing the vectors of development of the Ukrainian economy, it is important to realize that the variety of approaches to classification of banking risks, on the one hand, allows analyzing and identifying the existing types of risks in detail, developing new approaches and methodological tools to minimize and manage them, and on the other - forms their multifactoriality at the stage of their effective management.

To date, using the theory of banking, common types of banking risks have been identified. Thus, in accordance with the guidelines for inspection of banks "Risk Assessment System" [15], approved by the Resolution of the NBU Board dated March 15, 2004, the National Bank of Ukraine established nine categories of risks.

The results of generalizing the research findings of most Ukrainian and foreign scientists allow to formulate a systematic idea of the author about categories and types of banking risks, to prove that, first of all, they should be grouped according to the existing classification features, presented in the form of a block diagram (Fig. 1).

The data presented in the block diagram demonstrate the author's vision of a refined approach to grouping banking risks based on selected classification features.

Regulations envisage that banks are required to manage all types of existing risks, such as credit, liquidity, interest rate, market, exchange rate, operational, reputational, compliance risk, and strategic risk. Risks directly or indirectly affect efficiency of the entire financial management system, indirectly - through the financial monitoring system, they influence effectiveness of combating money laundering and terrorist financing in general [16].

$\mathrm{H}$

owever, despite the existing classification, in practice, a chain of risks arises in banking - one provokes another, and then they act interconnectedly and interdependently, creating a complex effect on the overall result.

For example, operational risk - arises in the process of carrying out various types of operations due to errors, carelessness or fraud of bank employees. This risk may arise in relation to any product or service that can be used for money laundering and / or terrorist financing.

In particular, in the bank, the monitoring of suspicious transactions of customers may be organized ineffectively. As a result, untimely detection of these transactions or failure of their detection can lead to untimely application of measures aimed at their stopping or failure to take such measures. In turn, some employees of the bank may accidentally or intentionally establish relationships with suspicious customers, not taking advantage of the right of or not fulfilling requirements of the law on the refusal to open an account for customers. 


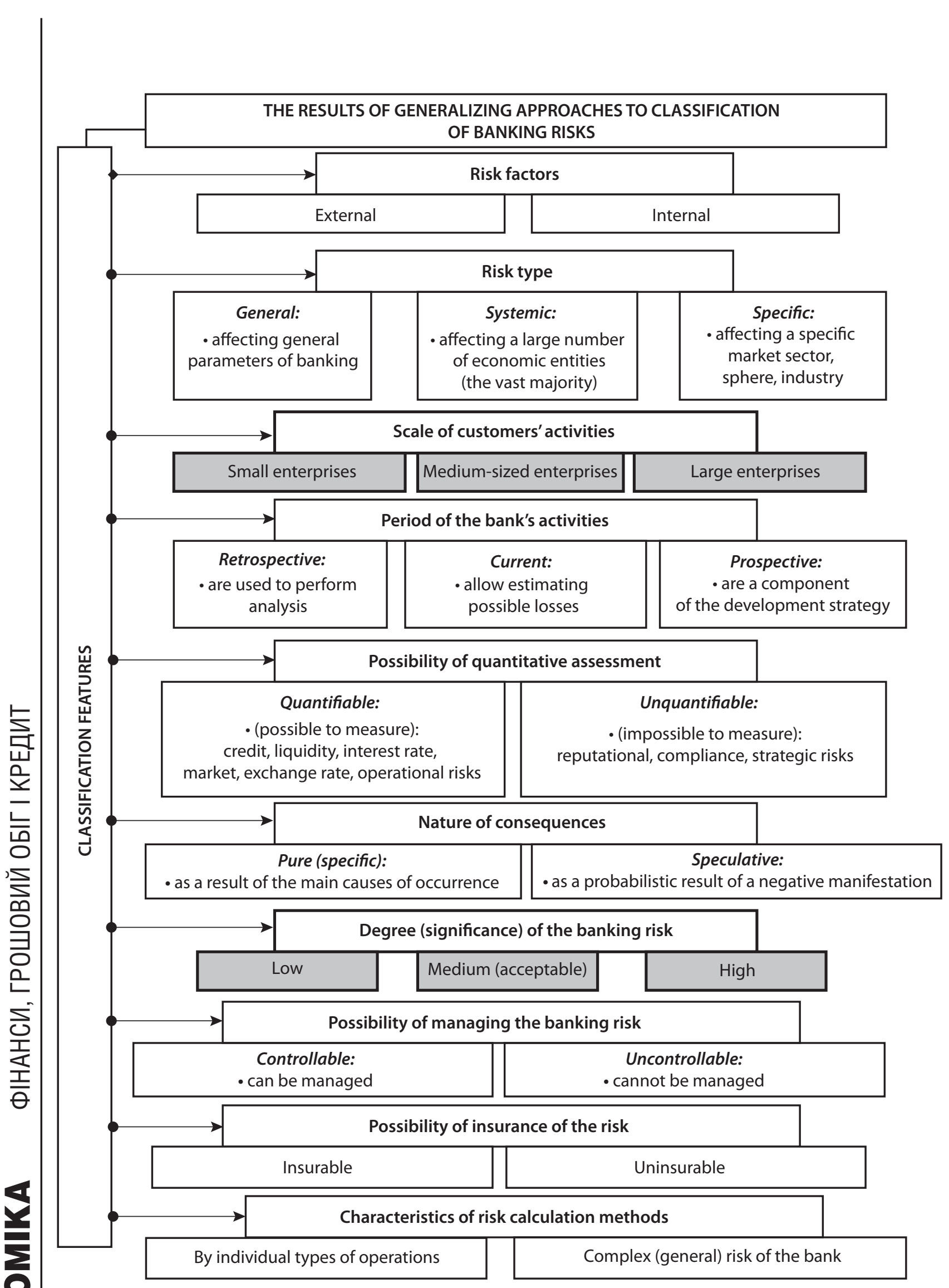

Fig. 1. Block diagram of the results of generalizing approaches to classification of banking risks 
Shortcomings and errors in management, control and implementation of banking operations can provoke a liquidity risk. The bank is exposed to a high level of compliance risk when it violates or ignores laws, rules and regulations adopted with the aim of combating money laundering and terrorist financing. The compliance risk can provoke the operational risk in case the national legislation is inadequate and, as a result, there is a risk of money laundering, which results in the reputational risk of the bank.

A bank that does not have an effective program for anti-money laundering and countering the terrorist financing significantly risks its business reputation. In turn, the reputation risk leads to a decrease in public confidence in the financial institution and, finally, there arises the liquidity risk.

$\mathrm{T}$ These properties of risks not only enhance their negative long-term impact and complicate the forecasting but also complicate the procedures for developing and applying measures aimed to protect the bank against their negative impact.

Researchers O. O. Hlushchenko, I. B. Semehen, in monograph [12], present the results of their study of the relationship between the risk of money laundering and typical banking risks and note that this risk is associated with the operational risk, which arises from inaccurate, erroneous or criminal acts, errors in internal processes and systems, or as a result of external influence.

In the course of the research highlighted in [17], the authors also found that the risk of money laundering and terrorist financing is closely related to the operational risk and reliability of banks.

The opinion of O. V. Utkina is worth noticing, "determining the degree of correlation of typical banking risks with risks of money laundering, we can see that the occurrence of the latter is significantly affected by operational and compliance risks" [18].

Based on the aforementioned statements of the researchers, it can be concluded that typical banking risks are interrelated with the risk of money laundering and most scientists argue that the risk of money laundering is most closely related to the operational risk.

The concept "money laundering" (ML) should be considered as activities that are constantly being transformed, therefore law enforcement agencies around the world are working to detect specific methods used by criminals. Countering the financing of terrorism is of utmost importance after the September 2001 attack in New York. In recent years, there has been an increase in terrorist organizations in almost all regions of the world. A continuous analysis of these phenomena is an indispensable condition for the development of timely and effective countermeasures [19].

The basis for the functioning of an effective system for anti-money laundering and countering the financing of terrorist is the creation of a regulatory framework that must comply with the international standards and recommendations the FATF [20], an inter-governmental body that develops anti-money laundering policies and promotes their implementation, both nationally and internationally.

The increased requirements of the FATF, the World Bank and the International Monetary Fund are a result of the consolidated efforts of the world community to combat money laundering, terrorist financing, and the financing of the proliferation of weapons of mass destruction. The penetration of criminal proceeds into business constitutes a real danger for the development of economic activities of economic entities, results in destabilization of the existing financial and monetary systems, decline in the welfare of the population, etc.

$\mathrm{O}$ ne of the most developed in Ukraine is financial monitoring of banking institutions [10] since it is the current system of financial monitoring that allows predicting the emergence of factors that adversely affect the stability of banks due to their vulnerability to ML / TF risks.

According to the Strategy for Development of the System for Prevention and Counteraction to Legalization (Laundering) of Proceeds from Crime, Terrorist Financing and the Financing of Proliferation of Weapons of Mass Destruction for the period till 2020 [21], the main dimensions are the consistent and effective fight against corruption and the improvement of forms and methods of the riskbased approach (RBA) in the field of financial monitoring.

The fundamental changes in the financial monitoring system include the development of mechanisms to improve the RBA. The existing relationship between the processes of laundering money, received as a result of corruption acts, indicates the relevance of preventing and combating corruption risks when applying the RBA in the financial monitoring system.

Article 14 of Law [22], which determines the powers of bodies of state financial monitoring, envisages their obligation to exercise supervision of activities of the relevant reporting entities (REs) in the field of prevention and counteraction to legalization (laundering) of proceeds from crime, terrorist financing and the financing of proliferation of weapons of mass destruction, in particular, by conducting scheduled and unscheduled inspections, including desktop inspections, in the manner established by the relevant body of state financial monitoring, which, according to Law [22], performs the functions of regulation and supervision of the RE.

Bodies of state financial monitoring apply the RBA in the planning and conducting corresponding inspections.

The list of REs included in the audit plan is compiled by bodies of state financial monitoring, based on the RBA and with regard to the results of their assessment of REs' vulnerability to ML / TF risks.

The procedures (criteria) for assessing the risks of using REs for the purpose of legalization (laundering) of proceeds from crime, terrorist financing and the financing of proliferation of weapons of mass destruction, developed by each body of state financial monitoring for its subordinate REs, take into account the features of these REs and are somewhat different. 
A ccording to the National Risk Assessment of Prevention and Counteraction to Legalization (Laundering) of Proceeds from Crime, Terrorist Financing and the Financing of Proliferation of Weapons of Mass Destruction 2016 [23], in Ukraine, for an effective risk management, it is proposed: carrying out periodic sectoral assessment by bodies of state financial monitoring of REs' vulnerability to ML / TF risks; using the results of sectoral risk assessment when planning inspections of REs for their compliance with the legislation in the field of AML / CFT; developing and adopting by the Ministry of Economic Development and Trade the regulatory act required for the adoption of the RBA to implement the supervision in the field of AML / CFT [7].

For functional modeling of a specific economic process IDEF0 is used. In the presented model, the author's contribution is to visualize its main elements through a set of actions, in the process of constructing the model they transform into separate blocks according to the principle of functional decomposition of systems (breaking the system into fragments). The decomposition of the model results in the creation of a set of hierarchically ordered and interconnected diagrams based on four basic concepts: control, mechanism, input, output.

Block A0 "Decomposition of the process of creating a model for customer risk management in the context of RBA implementation" consists of the stages shown in Fig. 2.

The block "Decomposition of the process of creating a model for customer risk management in the context of RBA implementation" consists of 3 stages:

Stage A1 - "Analysis of the external and internal environment of customer risk management in the RE".

Stage A2 - "Formation and approbation of the customer risk map".

Stage A3 - "Implementation of measures to control high-risk customers".
As can be seen from Fig. 3, Stage 1 implies analysis of the external environment (globalization aspect) and analysis of the internal environment, namely, the nature, structure and complexity of the activity, the variety of operations (their volumes and sizes), the specialization of customers, services and activities of the RE.

The next stage of the RBA application is the formation and validation of the RE's customer risk map, which consists of 3 steps: identification (detection) of ML / FT risks to form the customer risk map (A21); structuring of the risks and criteria for assessing ML / FT risks (risk criteria) by geographical location, type of customer, type of goods / services) and levels of risk (A22); classification of the RE's customers and identification of financial transactions that are at risk and can be subject to internal financial monitoring (A23) (Fig. 4).

REs are required to apply the RBA in their activities, taking into account certain risk criteria, namely, those associated with the geographical location of the country of registration of a customer or institution, with its customers and the type of goods / services the RE sells to the client. The RBA should be proportional to the nature and scale of activity of the RE.

$\mathrm{R}$ isk assessment is carried out in relation to customers who are provided with financial or other services and / or with whom business (contractual) relations are established, taking into account the requirements and recommendations for risk management identified and provided by the relevant bodies of state financial monitoring, which perform the functions of state regulation and supervision of activities of relevant REs. For the first time, the level of risk is determined and fixed by the entity when establishing business (contractual) relations with a customer [24].

The identification of ML / FT risks associated with the geographical location of the country of registration of

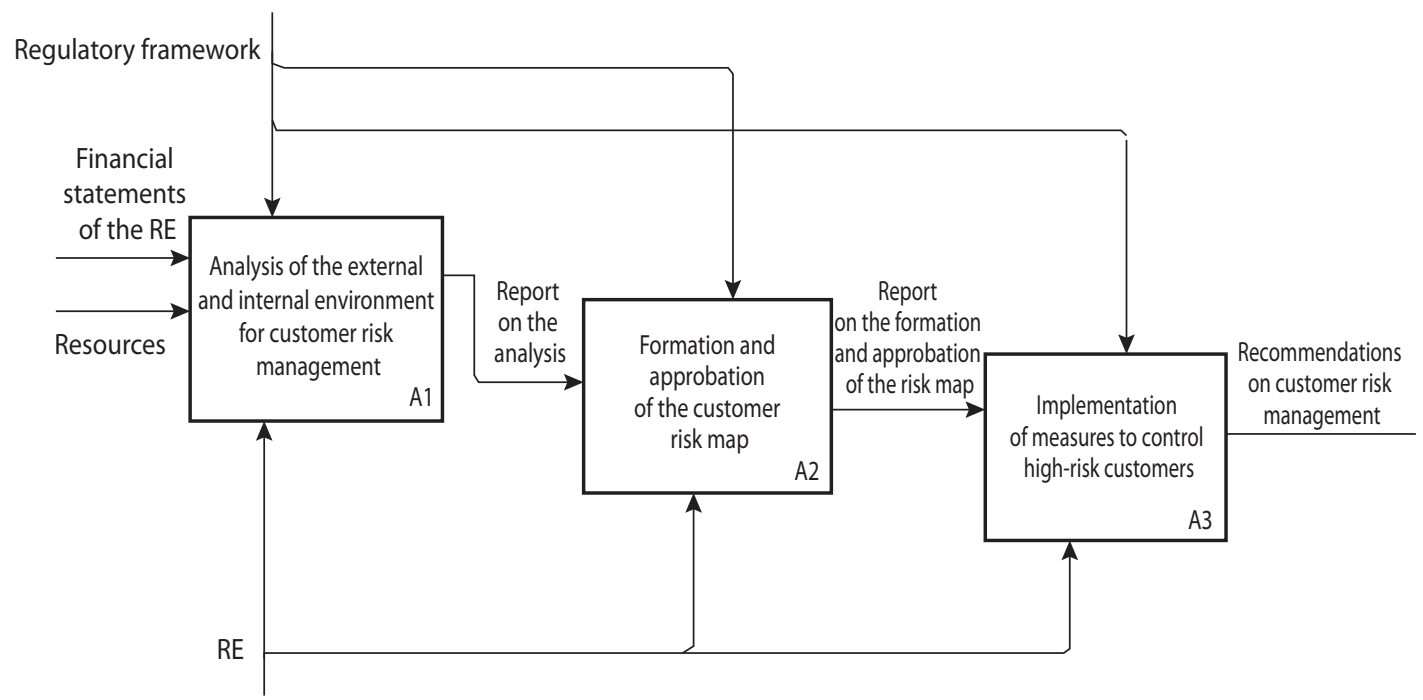

Fig. 2. Decomposition of the process of creating a model for customer risk management in the RE in the context of RBA implementation 


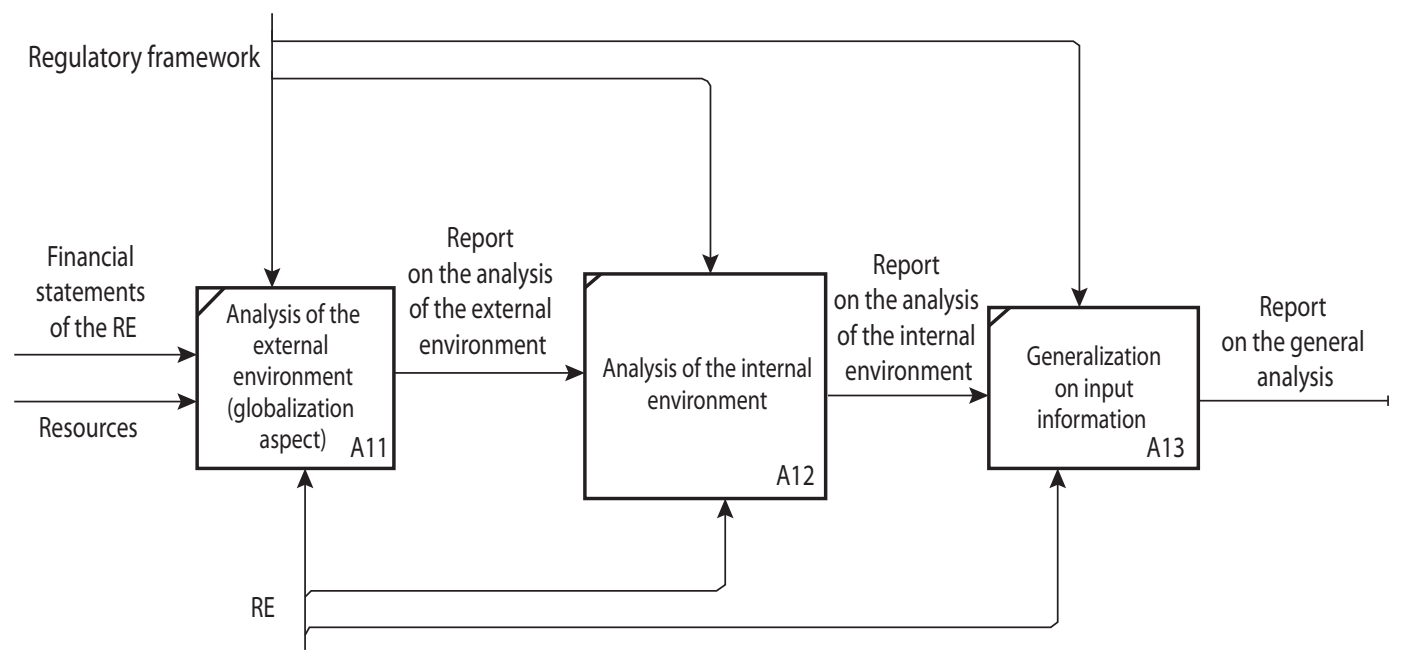

Fig. 3. Decomposition of the process of analyzing the external and internal environment of customer risk management in the RE

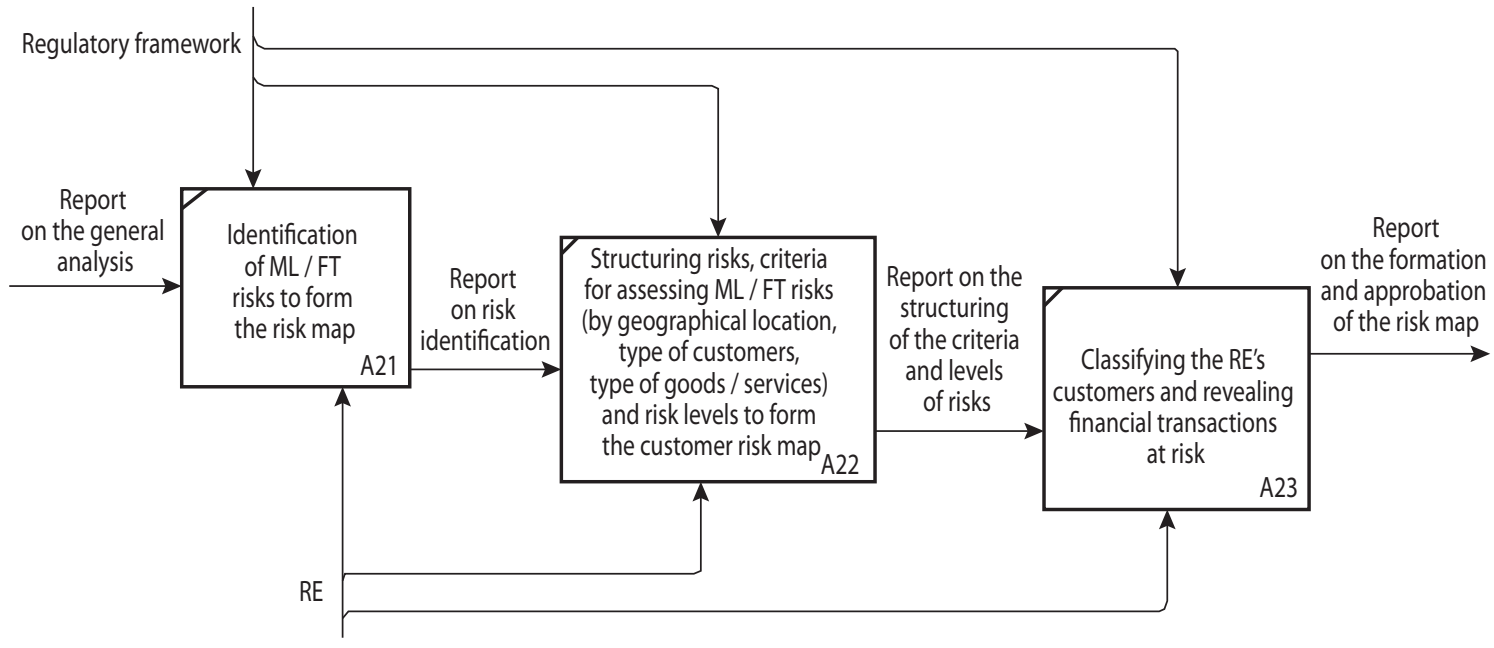

Fig. 4. Decomposition of the customer risk mapping in the RE

a customer or institution, with its customers and the type of goods / services, to the extent that they can be identified will allow the RE to determine and apply appropriate control measures to minimize these risks.

$\mathrm{T}$ The final stage implies applying measures to control high-risk customers. The structure of this stage consists of 4 steps: developing measures to control high-risk customers, aimed at reducing the risk level to acceptable (A31); applying customer control measures (monitoring transactions, services, channels), increasing the frequency of reviewing business relations, improving the $\mathrm{KYC}$ procedure, increasing the systematic control and ensuring the completeness of data on highrisk customers (A32); the RE's refusal to establish / extend business relations (including by terminating contractual relationships, closing the account) or continue business relationships with the customers (A33); informing the State Financial Monitoring Service on financial transactions of customers (A34). Applying appropriate control measures provides REs with the ability to minimize ML / FT risks associated with high-risk customers. REs are obliged to implement the monitoring of and to report on suspicious activities and large transactions, to collect the necessary identification information on the customer when the specified money threshold is exceeded (Fig. 5).

It should be noted that for non-compliance with the requirements of regulations for financial monitoring, a fine is imposed. For legal entities, the maximum sanction applicable is the fine of up to 3000 non-taxable minimum incomes, for non-legal entities - up to 200 non-taxable minimum incomes. The maximum amount of the fine depends on the body of the offense. In addition, in case of a repeated similar violation within one year, the body of the state financial monitoring can restrict, suspend or cancel the license or other special permit for the right to carry out certain types of activities by the RE.

The sanctions for violation of the rules of financial monitoring are rather strict: a fine is always a financial loss, but suspension or cancellation of a license can cause 


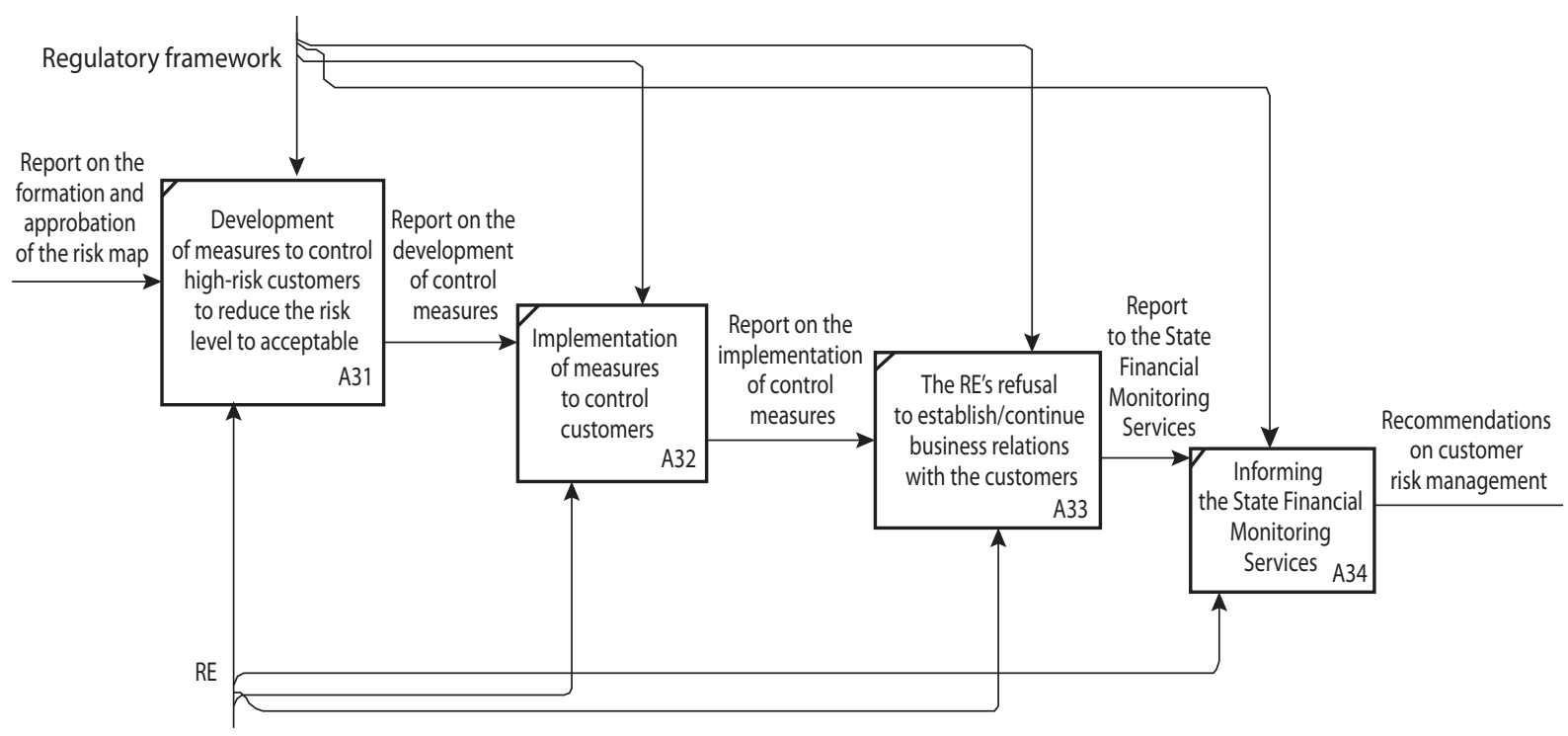

Fig. 5. Decomposition of the process of implementing measures to control the RE's high-risk customers

a greater damage, which in turn will lead to the inability to carry out business activities. Violations of the legislation governing activities in the field of counteracting money laundering are recorded by officials of the State Financial Monitoring Service when supervising activities of REs, in particular, by conducting scheduled and unscheduled inspections, including field or off-site audits. Violations are recorded in relevant reports on REs' audits.

The need for adopting the RBA is substantiated not only by requirements of international organizations, documents and Ukraine's striving for European integration but also by objective facts revealed when analyzing the data of the national risk assessment.

\section{CONCLUSIONS}

Based on the results of the study, the following conclusions were made. Developing the financial services market in Ukraine, maintaining its stability and reliability of financial institutions is a strategic task of state regulation and supervision. The relevance of the study is confirmed by the amendments to the Draft Law of Ukraine "On Prevention and Counteraction to Legalization (Laundering) of Proceeds from Crime, Terrorist Financing and the Financing of Proliferation of Weapons of Mass Destruction" adopted in the first reading in November 2019 [25]. The Law changes the development paradigm of the system of financial monitoring trough adopting the RBA, in particular, as regards risk assessment of REs that is based on analyzing a set of certain criteria and can be used to measure the RE's vulnerability to ML / FT risks.

According to the Draft Law, it is the risk management process itself, i.e., financial institutions' taking measures to create and ensure the functioning of the risk management system, including, inter alia, identifying (detecting), assessing / reassessing (measuring), monitoring, and controlling risks in order to minimize them, that changes the priorities of the financial monitoring system.
The Law increases the amount of a financial transaction subject to mandatory financial monitoring to UAH400 thousand, and decreases the number of characteristic features of such transactions from 17 to 4 :

+ transactions performed by politically exposed persons and their family members;

+ international transfers;

+ cash transactions (cash deposit and withdrawal, transfer);

+ transactions with banks / participants from countries that do not comply with the FATF recommendations.

Adopting the RBA, which is specifically aimed at identifying (detecting), assessing (reassessing) and understanding ML / FT risks, as well as taking appropriate risk management measures in a way and volume that ensure effective minimization of these risks depending on their level [25], in the future, should be based on the developed conceptual, scientific and methodological recommendations for identifying (detecting), assessing / reassessing (measuring), and controlling risks.

Studying regulatory and organizational aspects of the implementation of financial investigations in the financial monitoring system is an urgent task to be solved by scientists and is of scientific and practical value.

7 hus, the current regulation of the RBA in the field of AML / CFT at the level of competent authorities in Ukraine is not fully effective, as it is based on the established and promulgated formal criteria for identifying and assessing ML / FT risks. To ensure the implementation of an effective RBA, it is necessary to apply objective measurement of REs' vulnerability to ML / TF risks, based on the processing and analysis of a large number of performance indicators to identify ML / FT schemes.

Adopting the RBA will provide for certain advantages, in particular, more efficient risk and expense mana- 
gement. This is possible due to individualized approach to the formation of risk criteria with regard to the level of detection and assessment of the risk. Accordingly, it will allow not to divert the resources of the system for anti-money laundering and countering the financing of terrorist to service unnecessary processes focusing only on the risks identified.

\section{LITERATURE}

1. Rose P. S., Kolari J. W. Financial institutions: Understanding and Managing Financial Services. Richard \& Irwin, $1994.766 \mathrm{p}$.

2. Turk M. C. Reframing International Financial Regulation After the Global Financial Crisis: Rational States and Independence, Not Regulatory Networks and Soft Law. Michigan Journal of International Law. 2014. Vol. 36. Issue 1. P. 59-128. URL: https://repository.law.umich.edu/cgi/viewcontent. cgi?article $=1072 \&$ context $=$ mjil

3. Внукова Н. М. Управління ризиками фінансових установ у сфері фінансового моніторингу. Наукові записки Начіонального університету «Острозька академія». Серія «Економіка». 2018. № 8. С. 64-68.

4. Внукова Н. М., Гонтар Д. Д., Воротинцев М. М. Інструментарій управління ризиками «відмивання» коштів на основі визначення рівня зв'язності фінансових компаній та кредитних спілок. Development Management. 2018. Vol. 4. Issue 4. P. 40-51.

Doi:10.21511/dm.4(4).2018.04.

5. Андрійченко Ж. О., Літвінова С. О. Статистичне обгрунтування необхідності запровадження ризик-орієнтованого підходу у сфері фінансового моніторингу в Україні. Проблеми і перспективи розвитку підприємництва. 2017. № 2. C. 49-54.

6. Андрійченко Ж. О. Фінансовий моніторинг у системі управління ризиками ринків фінансових послуг // Розвиток системи управління ризиками ринків фінансових послуг: монографія / наук. ред. та кер. кол. авт. Н. М. Внукова. Харків : Ексклюзив, 2014. С. 140-150.

7.Пономаренко В.С., Внукова Н. М., Колодізєв О. М., Ачкасова С. А. Вплив державного регулювання і нагляду на розвиток ризик-орієнтованої системи фінансового моніторингу України. Фінансово-кредитна діяльність: проблеми теорії та практики. 2019. Том 2. № 26. С. 419-429. URL: http://fkd.org.ua/article/view/171986/173468

8. Ачкасова С. А. Удосконалення державного регулювання у сфері фінансового моніторингу в Україні при європейській інтеграції // Сучасні загрози безпеці на національному та регіональному рівнях : зб. мат. наук.-теор. конф. (м. Суми, 19-20 квітня 2018 р.). Суми : Сумський державний університет, 2018. С. 3-6.

9. Барановський О. І. Філософія безпеки : монографія : у 2 т. Київ : УБС НБУ, 2014. Т. 2 : Безпека фінансових інститутів. 716 с.

10. Єгоричева С. Б. Організація фінансового моніторингу в банках : навч. посіб. Київ : Центр навчальної літератури, 2014. 292 с.

11. Коваленко В. В., Дмитров С. О., Єжов А. В. Міжнародний досвід у сфері запобігання та протидії відмиванню доходів, одержаних злочинним шляхом, та фінансуванню тероризму : монографія. Суми : УАБС НБУ, 2007. 140 с
12. Глущенко О. О., Семеген І. Б. Антилегалізаційний фінансовий моніторинг: ризик-орієнтований підхід : монографія / за заг. ред. Р. А. Слав'юка. Київ : УБС НБУ, 2014. 386 с.

13. Колодізєв О. М., Плескун І. В. Систематизація практичних рекомендацій щодо пошуку моделей оцінки, контролю та ефективного управління ризиками для забезпечення протидії легалізації «брудних коштів» // Управління стійким розвитком економіки: теоретичні та практичні аспекти : колективна монографія / за ред.д.е. н., проф. В.В.Прохорової. Харків, 2018. С. 264-278.

14. Система ризик-менеджменту в банках: теоретичні та методологічні аспекти : колективна монографія / за ред. В. В. Коваленко. Одеса : ОНЕУ, 2017. 304 с.

15. Методичні вказівки з інспектування банків «Система оцінки ризиків» : схвалено Постановою Правління НБУ від 15.03.2004 р. № 104. URL: http://zakon5.rada.gov.ua/laws/ show/v0104500-04

16. Плескун І. В. Визначення рівня сукупного ризику банків в системі фінансового моніторингу. East European Science Journal. 2019. No. 7. Part 5. P. 23-29.

17. Чмутова І. М., Ткачова Є. О. Фінансова стійкість банку як індикатор ризику відмивання коштів та фінансування тероризму. Економіка і суспільство. 2018. Вип. 14. C. 867-875. URL: http://economyandsociety.in.ua/journal/14 ukr/125.pdf

18. Уткіна О. В. Система управління банківськими ризиками легалізації доходів, отриманих злочинним шляхом : дис. ... канд. екон. наук : 08.00.08. Київ, 2019. 219 с.

19. Коротюк В., Карманов $\epsilon$. Деякі аспекти правового регулювання боротьби з відмиванням грошей у банківській системі. Все про бухгалтерський облік. 2011. № 56. C. 17-19.

20. Група з розробки фінансових заходів боротьби 3 відмиванням грошей (FATF) URL: http://www.sdfm.gov.ua/ content/File/Site_docs/2008/20.09.08/40_ukr_new-3.htm

21. Стратегія розвитку системи запобігання та протидії легалізації (відмиванню) доходів, одержаних злочинним шляхом, фінансуванню тероризму та фінансуванню розповсюдження зброї масового знищення на період до 2020 року : схвалена Розпорядженням Кабінету Міністрів України від 30.12.2015 № 1407-p. URL : http://zakon0.rada.gov.ua/laws/ show/1407-2015-p

22. Закон України «Про запобігання та протидію легалізації (відмиванню) доходів, одержаних злочинним шляхом, фінансуванню тероризму та фінансуванню розповсюдження зброї масового знищення» від 14.10.2014 р. № 1702-VII. URL: http://zakon3.rada.gov.ua/laws/show/1702-18

23. Звіт про проведення національної оцінки ризиків у сфері запобігання та протидії легалізації (відмиванню) доходів, одержаних злочинним шляхом, та фінансуванню тероризму. Київ, 2016. URL: http://www.sdfm.gov.ua/content/ file/Site_docs/2016/20161125/zvit_ukr.pdf

24. Державна служба фінансового моніторингу України / Основні завдання структурних підрозділів. 01.07.2016. URL: http://www.sdfm.gov.ua/articles.php?cat_ id=106\&amp;art_id=22591\&amp;lang=uk

25. Проект Закону України «Про запобігання та протидію легалізації (відмиванню) доходів, одержаних злочинним шляхом, фінансуванню тероризму та фінансуванню розповсюдження зброї масового знищення» від 01.11.2019 p. URL: http://w1.c1.rada.gov.ua/pls/zweb2/ webproc4_1?pf3511=66949 


\section{REFERENCES}

Achkasova, S. A. "Udoskonalennia derzhavnoho rehuliuvannia u sferi finansovoho monitorynhu v Ukraini pry yevropeiskii intehratsii" [Improvement of State Regulation in the Field of Financial Monitoring in Ukraine with European Integration]. Suchasnizahrozy bezpetsi na natsionalnomu ta rehionalnomu rivniakh. Sumy: Sumskyi derzhavnyi universytet, 2018. 3-6.

Andriichenko, Zh. O. "Finansovyi monitorynh u systemi upravlinnia ryzykamy rynkiv finansovykh posluh" [Financial Monitoring in the Risk Management System of Financial Services Markets]. In Rozvytok systemy upravlinnia ryzykamy rynkiv finansovykh posluh, 140-150. Kharkiv: Ekskliuzyv, 2014.

Andriichenko, Zh. O., and Litvinova, S. O. "Statystychne obgruntuvannia neobkhidnosti zaprovadzhennia ryzyk-oriientovanoho pidkhodu u sferi finansovoho monitorynhu v Ukraini" [Statistical Justification of the Necessity of Implementation RiskBased Approach in Financial Monitoring in Ukraine]. Problemy $i$ perspektyvy rozvytku pidpryiemnytstva, no. 2 (2017): 49-54.

Baranovskyi, O. I. Filosofiia bezpeky [Security Philosophy], vol. 2 : Bezpeka finansovykh instytutiv. Kyiv: UBS NBU, 2014.

Chmutova, I. M., and Tkachova, Ye. O. "Finansova stiikist banku yak indykator ryzyku vidmyvannia koshtiv ta finansuvannia teroryzmu" [Financial Stability of the Bank as a Risk Indicator of Money Laundering and Terrorism Financing]. Ekonomika i suspilstvo. 2018. http://economyandsociety.in.ua/ journal/14_ukr/125.pdf

"Derzhavna sluzhba finansovoho monitorynhu Ukrainy" [State Financial Monitoring Service of Ukraine]. Osnovni zavdannia strukturnykh pidrozdiliv. 01.07.2016. http://www.sdfm.gov. ua/articles.php?cat_id=106\&amp;art_id=22591\&amp;lang=uk

"Hrupa z rozrobky finansovykh zakhodiv borotby z vidmyvanniam hroshei (FATF)" [Anti-money Laundering (FATF) Development Team]. http://www.sdfm.gov.ua/content/File/ Site_docs/2008/20.09.08/40_ukr_new-3.htm

Hlushchenko, O. O., and Semehen, I. B. Antylehalizatsiinyi finansovyi monitorynh: ryzyk-oriientovanyi pidkhid [Anti-organizational Financial Monitoring: a Risk-oriented Approach]. Kyiv: UBS NBU, 2014.

Kolodiziev, O. M., and Pleskun, I. V. “Systematyzatsiia praktychnykh rekomendatsii shchodo poshuku modelei otsinky, kontroliu ta efektyvnoho upravlinnia ryzykamy dlia zabezpechennia protydii lehalizatsii «brudnykh koshtiv»" [Systematization of Practical Recommendations on the Search for Models for Assessment, Control and Effective Risk Management for Counteraction to the Legalization of "Dirty Funds"]. In Upravlinnia stiikym rozvytkom ekonomiky: teoretychni ta praktychni aspekty, 264-278. Kharkiv, 2018.

Korotiuk, V., and Karmanov, Ye. “Deiaki aspekty pravovoho rehuliuvannia borotby z vidmyvanniam hroshei u bankivskii systemi" [Some Aspects of Legal Regulation against Money Laundering in the Banking System]. Vse pro bukhhalterskyi oblik, no. 56 (2011): 17-19.

Kovalenko, V. V., Dmytrov, S. O., and Yezhov, A. V. Mizhnarodnyi dosvid u sferi zapobihannia ta protydii vidmyvanniu dokhodiv, oderzhanykh zlochynnym shliakhom, ta finansuvanniu teroryzmu [International Experience in the Prevention and Combating of Money Laundering and Terrorist Financing]. Sumy: UABS NBU, 2007.

[Legal Act of Ukraine] (2004). http://zakon5.rada.gov.ua/ laws/show/v0104500-04
[Legal Act of Ukraine] (2014). http://zakon3.rada.gov.ua/ laws/show/1702-18

[Legal Act of Ukraine] (2015). http://zakon0.rada.gov.ua/ laws/show/1407-2015-p

[Legal Act of Ukraine] (2019). http://w1.c1.rada.gov.ua/ pls/zweb2/webproc4_1?pf3511=66949

Pleskun, I. V. "Vyznachennia rivnia sukupnoho ryzyku bankiv v systemi finansovoho monitorynhu" [Determination of the Level of the Aggregated Risk of Banks in the System of Financial Monitoring]. East European Science Journal, vol. 5, no. 7 (2019): 23-29.

Ponomarenko, V. S. et al. "Vplyv derzhavnoho rehuliuvannia i nahliadu na rozvytok ryzyk-oriientovanoi systemy finansovoho monitorynhu Ukrainy" [The Influence of Governmental Regulation and Supervision on the Development of the RiskOriented System of Financial Monitoring of Ukraine]. Finansovo-kredytna diialnist: problemy teorii ta praktyky. 2019. http:// fkd.org.ua/article/view/171986/173468

Rose, P. S., and Kolari, J. W. Financial institutions: Understanding and Managing Financial Services. Richard \& Irwin, 1994.

Systema ryzyk-menedzhmentu $v$ bankakh: teoretychni ta metodolohichni aspekty [Risk Management System in Banks: Theoretical and Methodological Aspects]. Odesa: ONEU, 2017.

Turk, M. C. “Reframing International Financial Regulation After the Global Financial Crisis: Rational States and Independence, Not Regulatory Networks and Soft Law". Michigan Journal of International Law. 2014. https://repository.law.umich. edu/cgi/viewcontent.cgi?article=1072\&context $=$ mjil

Utkina, O. V. "Systema upravlinnia bankivskymy ryzykamy lehalizatsii dokhodiv, otrymanykh zlochynnym shliakhom" [Banking Risk Management System for the Legalization of Proceeds of Crime]: dys. ... kand. ekon. nauk:08.00.08, 2019.

Vnukova, N. M. "Upravlinnia ryzykamy finansovykh ustanov u sferi finansovoho monitorynhu" [Financial Institutions Risks Management in the Field of Financial Monitoring]. Naukovi zapysky Natsionalnoho universytetu «Ostrozka akademiia». Seriia «Ekonomika», no. 8 (2018): 64-68.

Vnukova, N. M., Hontar, D. D., and Vorotyntsev, M. M. “Instrumentarii upravlinnia ryzykamy «vidmyvannia» koshtiv na osnovi vyznachennia rivnia zviaznosti finansovykh kompanii ta kredytnykh spilok" [Money Laundering Risk Management Tools Based on Determining the Level of Coordination of Financial Companies and Credit Unions]. Development Management, vol. 4, no. 4 (2018): 40-51. DOI:10.21511/dm.4(4).2018.04

Yehorycheva, S. B. Orhanizatsiia finansovoho monitorynhu $v$ bankakh [Organization of Financial Monitoring in Banks]. Kyiv: Tsentr navchalnoi literatury, 2014.

"Zvit pro provedennia natsionalnoi otsinky ryzykiv u sferi zapobihannia ta protydii lehalizatsii (vidmyvanniu) dokhodiv, oderzhanykh zlochynnym shliakhom, ta finansuvanniu teroryzmu. 2016" [Report on Conducting a National Risk Assessment in the Area of Preventing and Counteracting the Legalization (Laundering) of Proceeds of Crime and the Financing of Terrorism. 2016]. http://www.sdfm.gov.ua/content/file/ Site_docs/2016/20161125/zvit_ukr.pdf 